УПРАВЛІННЯ ПІДПРИЄМСТВОМ

UDC 658.018

O. I. Gonchar, Doctor of Economic Sciences, Professor, I. I. Polishchuk, Candidate of Economic Sciences, Associate Professor

\section{SYNERGIC APPROACH IN MARKETING POTENTIAL MANAGEMENT OF THE ENTERPRISE}

Urgency of the research. The main instrument of enterprise development in modern conditions is the marketing potential and its perfection. It determines the capabilities and ability to form the demand of consumers, respond promptly to its changes.

Target setting. Active position on the market, satisfaction of consumer expectations is a key factor in competitive advantages and entrepreneurial success as characteristics of marketing potential.

Actual scientific researches and issues analysis. Research on synergistic effects is taking place in the works of such scientists as Ansoff I., Yevstyhnieiev V., Mamedov M., Molchanov V., Pranhishvili I., Pryhozhyn I., Haken H. and others.

Uninvestigated parts of general matters defining. There is no general definition of "synergistic effect" term from the economic point of view. There is a need for research to develop the management of marketing potential and increase the competitiveness of enterprises.

The research objective. The article is devoted to the application principles substantiation of the synergistic approach in the managing the marketing potential of the enterprise practice.

The statement of basic materials. The authors substantiate that it is necessary to define the formation of a synergistic effect of the interaction of marketing potential elements in conditions of the environment and international integration dynamism as a strategic aspect of enterprise management, an instrument of competitive struggle and to emphasize its substantiation in strategic and tactical planning.

It is proved that it is expedient to carry out synergistic effect of marketing potential elements interaction classification on a functional basis and positioning of the marketing potential itself in the structure of the company's aggregate potential in order to identify them.

It is stated that the success of the enterprise activity, its position on the market and the possibility of development in the future is determined by the correctness of the formation and the strength of the relationship between the elements of marketing and aggregate potential.

Conclusions. Taking into account the synergistic effect of the interaction of the elements of the enterprise marketing potential provides the improvement of management mechanisms and forms the prospects for development.

Keywords: Marketing potential; enterprise; synergy; entropy; result; opportunities; management.

DOI: 10.25140/2410-9576-2017-2-3(11)-29-33
УДК 658.018

О. І. Гончар, д. е. н., профресор

I.I. Поліщук, к. е. н., доцент

\section{СИНЕРГІЙНИЙ ПІДХІД В УПРАВЛІННІ МАРКЕТИНГОВИМ ПОТЕНЦІАЛОМ ПІДПРИЄМСТВА}

Актуальність теми дослідження. Головним інструментом розвитку підприємства в сучасних умовах $\epsilon$ маркетинговий потенціал, його досконалість. Він визначає можливості $і$ здатності формувати попит споживачів, оперативно реагувати на його зміни.

Постановка проблеми. Активна позиція на ринку, задоволення очікувань споживачів, як характеристики маркетингового потенціалу, $\epsilon$ ключовим фрактором конкурентних переваг і підприємницького успіху.

Аналіз останніх досліджень і публікацій. Дослідження проблематики синергійних ефектів має місце у працях: Ансофра І., Євстигнєєва В., Мамедова М., Молчанова В., Прангішвілі І., Пригожина І., Хакена Г. та ін.

Виділення недосліджених частин загальної проблеми. Відсутнє узагальнююче визначення "синергійного ефректу» з економічної точки зору. Існує необхідність дослідження з метою розвитку управління маркетинговим потенціалом та підвищення конкурентоспроможності підприємств.

Постановка завдання. Стаття присвячена обірунтуванню засад застосування синергійного підходу в практиці управління маркетинговим потенціалом підприємства.

Виклад основного матеріалу. Авторами обгрунтовано, що формування синергійного ефекту взаємодії елементів маркетингового потенціалу в умовах динамізму середовища і міжнародної інтеграції, необхідно визначати як стратегічний аспект управління підприємством, інструмент конкурентної боротьби і акцентувати увагу на його обгрунтуванні у стратегічному $i$ тактичному плануванні.

Доведено, що для виявлення синергійного ефекту взаємодії елементів маркетингового потенціалу доцільно здійснити їх класифрікацію за фрункціональною ознакою, та позиціонування самого маркетингового потенціалу в структурі сукупного потенціалу підприємства.

Констатовано, що успішність діяльності підприємства, його позиції на ринку і можливість розвитку у майбутньому, обумовлюється правильністю формування і силою взаємозв'язку елементів маркетингового і сукупного потенціалу.

Висновки. Врахування синергійного ефекту взаємодії елементів маркетингового потенціалу підприємства забезпечує удосконалення механізмів управління та формує перспективи розвитком.

Ключові слова: маркетинговий потенціал; підприємство; синергія; ентропія; результат; можливості; управління. 


\section{УПРАВЛІННЯ ПІДПРИЕМСТВОМ}

Urgency of the research. International integration and globalization increases uncertainties and risks of entrepreneurial activity. The socioeconomic changes taking place in the country economy have a significant effect on the development of business structures, the peculiarities of management activity. The maintenance value of development opportunities forms the marketing potential of the enterprise, its development and perfection, the capabilities and ability to study and form the demand of consumers, to respond promptly to its changes.

Target setting. In up to date conditions active position on the market, satisfaction of consumer expectations is a key factor in competitive advantages and entrepreneurial success as characteristics of marketing potential.

Actual scientific researches and issues analysis. In recent years, the concept of synergy has extended its definition and application in the practice of management activities. In economic literature, there is no consensus on the interpretation of both the definition of synergy and entropy. Research on these questions is taking place in the works of such scientists as Ansoff I., Yevstyhnieiev V., Mamedov M., Molchanov V., Pranhishvili I., Pryhozhyn I., Haken H. and others. Despite the large number of scientists involved in this issue, there is no generally accepted definition from the economic point of view today, particularly as the application in business management practice. Therefore, there is a need to study this category in order to develop the theory of marketing potential management and increase the competitiveness of enterprises in modern conditions.

The research objective. To generalize the existing scientific approaches to determine the synergy effect of the system and substantiation of the principles of its application in the practice of managing the marketing potential of the enterprise in modern conditions.

The statement of basic materials. Problems of forming and ensuring the effectiveness of marketing potential of the enterprise are caused by the complexity of identification, balancing and research of its structure, selection of participants in the process of management, having a certain set of available and hidden resources and opportunities for their implementation; the development of optimal mechanisms of interaction, the dynamism of the internal and external environment of the enterprise. Numerous changes arise under the influence of social, economic, legal, psychological, physiological factors; scientific and technological progress and have a direct impact on the marketing potential and on the sphere of its implementation as it is the segment of the enterprise market. On the other hand, all this affects the change in the structure of the marketing potential of the enterprise. The more optimal elements of the potential are interconnected, the more effective they are implemented, they form a "synergistic effect" of interaction! and provide growth of the aggregate potential of the enterprise.

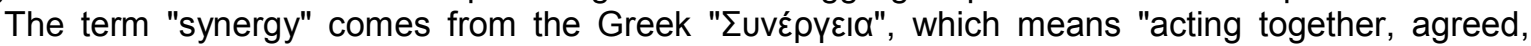
common." According to Hermann Hacken [1] synergetics is engaged in the study of systems that consist of a large number of parts, components or subsystems, i. e. details that interact in a complicated way. We agree with this opinion that synergism manifests itself in the combination of various spheres of activity within one organization, as well as in increasing the effectiveness of the interaction of elements within a single system. In the context of our research it is a system for managing the marketing potential of an enterprise.

The synergistic effect should be considered as a variant of the reaction to the total effect of two or more factors, characterized by the fact that this action exceeds the action provided by each factor autonomously [2; 302]. I. Ansoff [2] considered the synergistic effect as a result of one of the reaction variants (positive or negative) on the total effect of factors that are characterized by the fact that the action exceeds (or reduces) the action provided by each factor separately.

The formation of the synergistic effect of the interaction of elements of the marketing potential of an enterprise in conditions of the dynamism of the environment and international integration, must be defined as a strategic aspect of enterprise management, an instrument of competition (in the domestic and international markets) and to emphasize its substantiation in the process of strategic and tactical planning.

In our opinion in order to detect the synergistic effect of the interaction of elements of marketing potential it is necessary to classify them according to the functional feature, and to position the marketing potential itself in the structure of the aggregate potential of the enterprise [3]. Such a classification will 


\section{УПРАВЛІННЯ ПІДПРИЕМСТВОМ}

ensure the identification, formation and implementation of such system-forming properties as the ability of the elements of the potential for self-development, interchange, dynamism and variability of the relationships between them, a quick and effective response to external influences.

So speaking about the synergistic effect of managing the marketing potential of an enterprise, one should understand the effect of the abilities development in realizing market opportunities, studying, satisfying and forming consumer demand, managing the market segment, implementing statutory activities and initiating the emergence of new opportunities, achieving a maximum positive result at the expense of a positive systemic effect.

Hence, the synergy of the elements of the enterprise marketing potential is to obtain an additional positive effect from the interaction of all its elements compared with the simple sum of their results. Mathematically this can be represented using the formula:

$$
E M P=\sum_{i=1}^{n} \int\left(e_{1}, e_{2}, e_{3}, \ldots, e_{n}\right), E M P \rightarrow e_{m}+1
$$

where EMP stands for enterprise marketing potential;

$e_{1}, e_{2}, e_{3}, \ldots, e_{n}$ are the elements of the enterprise marketing potential.

Then, development of the enterprise marketing potential should be considered as a function, which depends on a certain number of (plural) arguments. The synergistic effect of the interaction of the enterprise marketing potential elements will be formed as a result of optimization of the relationship between the elements of the enterprise potential, which ensures the possibility of achieving greater results than in those cases where they function separately:

$$
F(E M P) \geq \sum e e i
$$

where eei is the $i^{\text {th }}$ element of the enterprise marketing potential allocated for research.

Applying entropy in managing the enterprises potential in modern conditions, it should be taken into account the fact that the enterprise is an open system, which inherent processes of sharing resources with the external environment. Thus, "enterprise" and "enterprise potential" systems tend to acquire certain changes under the influence of external factors. And, though, we are talking about "nongovernmental management", we should consider the degree of entropy of the enterprise potential and its marketing component.

This concept has been used recently in economy but recently it attracted the attention of many scientists. The fact is that the entropy of the production system must indicate productive activity effectiveness, which is a very important point in assessing the potential of a particular enterprise.

Consequently, the effectiveness of management capacity can be evaluated by the state of entropy in the enterprise, e. i. because of the chaos that "reigns" in this system and which affects the activities of both the system as a whole and each of its units. In our opinion, from the position of entropy, the enterprise has the following characteristics:

1) the system is dynamic, stochastic;

2) using a certain control algorithm the control structure represents the corresponding control signals on the inputs of the controlled subsystem with any management act for choosing the best controlling influence, since the purpose of management is the ability to select the optimal mode of the control object operation;

3) the managed system outputs signals in the form of finished products, services, innovations, economic and social effects, products of interaction with the environment;

4) the behavior of the system at any given time is probabilisticly determined by the output signals, its internal pre-conditions and the stage at a given time; in turn, the change in output signals is probabilistic due to the change in input signals as well as the internal states of the system, relating to this time point;

5) the movement of the system occurs in a certain trajectory, the ultimate point of which is the purpose of the enterprise potential managing. 


\section{УПРАВЛІННЯ ПІДПРИЕМСТВОМ}

The effect of entropy arises because there is no absolutely isolated system in nature, so there is a constant process of sharing resources, energy, and information between systems. This process is due to the fact that everything in nature tends to balance, but this is only possible with a constant decay process. So in terms of physics we can say that each system including the marketing and aggregate potential of the enterprise can be characterized in terms of both entropy and negentropy.

Another characteristic of the enterprise from the point of view of thermodynamics is that entropy occurs under the influence of competition for information, energy, resources. This explains the fact that some enterprises receive gradual changes in order to streamline their system as well as to improve it. Others turn off activities and leave the market.

Summarizing scientific studies the existing definition of entropy can be classified in three groups: entropy as a measure of uncertainty, as a lack of information, as a measure of disordered system. In our opinion, in the management of the marketing and aggregate potential of the enterprise the definition of "entropy as a measure of uncertainty" deserves the greatest attention. There is a system disorderliness and lack of information about it because of uncertainty that affects all management processes, including efficiency management and development perspectives formation.

Noting that the synergistic effect is a multi-faceted and ambiguous concept that depends on many factors it is not always possible to achieve it. The main causes of the zero result for different enterprises are individual and depend on the scope of synergy. Factors that may adversely affect the law of synergy can be external (for example, political factors, geopolitical issues, regulatory and legislative changes), and internal ones like weaknesses in capacity management.

So we can say that the success of the enterprise, its position on the market and the possibility of development in the future is conditioned by the correctness of the formation and the strength of the relationship between the elements of its marketing, first and foremost, of aggregate potential.

The source of these business benefits is a more efficient use of resources and business opportunities, an active market position, complementary technologies and products they produce, the ability to reduce current costs and other similar factors. The principle of synergy is realized with the use of property on the basis of interconnected management, associations, corporations, consortia, corporations and other associations of legal and natural persons. In conditions of increasing market risks and strengthening competition, the best result is obtained by economic entities engaged together in economic activity (creating clusters), since in this case their aggregate property potential and the marketing component in particular is higher comparing to the single market representation .

Conclusions. Managing the marketing and aggregate potential of the company implies an impact on the processes of its formation, use and development and requires the development of an integrated management system that combines the management of all processes and resources of the functional capabilities, their transformations. In the current conditions of globalization and international integration, the creation of such system should take into account the peculiarities of industrial enterprises in a certain area, modern management developments, carried out in accordance with the goals of enterprises and external factors of influence.

The traditional approach to managing a company based on a linear representation of the functioning of socio-economic production systems is not viable today. Modern enterprises are nonlinear systems that can build, structure themselves, only need is to initiate the desired trends of selfdevelopment through the processes of forming their potential in general and each element properly. The success of each enterprise is determined by the strength of the interconnection and interaction of elements of its potential and, first of all, marketing potential which is an element that provides market benefits.

The proposed approach to take into account the synergistic effect of the interaction of the enterprise marketing potential elements allows further refinement and improvement of mechanisms, approaches, principles and methods, development of a new methodology and practical recommendations for potential building and development management. 


\section{УПРАВЛІННЯ ПІДПРИЕМСТВОМ}

\begin{tabular}{|c|c|}
\hline Refe & Літ \\
\hline $\begin{array}{l}\text { 1. Haken, H. (2005). Informatsiia i samoorganizatsiia } \\
\text { Makroskopicheskii podkhod k slozhnym sistemam } \\
\text { [Information and Self-Organization: A Macroscopic Approach } \\
\text { to Complex Systems] (2nd ed.). Moscow: KomKniga [in } \\
\text { Russian]. } \\
\text { 2. Ansoff, I. (1989). Strategicheskoe upravlenie } \\
\text { [Strategic management]. Moscow: Economika [in Russian]. } \\
\text { 3. Gonchar, O. I. (2016). Anagement potential of the } \\
\text { company with regard flock business life. Scientific Bulletin of } \\
\text { Polissia, 7, 190-196 [in English]. }\end{array}$ & $\begin{array}{l}\text { 1. Хакен, Г. Информация и самоорганизация. Мак- } \\
\text { роскопический подход к сложным системам / Г. Хакен ; } \\
\text { пер. с англ.; предисл. Ю. Л. Климонтовича. - 2-е изд., } \\
\text { доп. - М. : КомКнига, 2005. - } 248 \text { с. } \\
\text { 2. Ансоффф, И. Стратегическое управление / И. } \\
\text { Ансоффф ; сокр. пер. с англ. ; науч. ред. и авт. предисл. Л. } \\
\text { И. Евенко. - М. : Экономика, 1989. - } 519 \text { с. } \\
\text { 3. Gonchar, O. I. Anagement potential of the company } \\
\text { with regard flock business life / O. I. Gonchar // Науковий } \\
\text { вісник Полісся. - 2016. - № } 3 \text { (7). - C. 190-196. }\end{array}$ \\
\hline
\end{tabular}

Received for publication 10.05 .2017

Бібліографічний опис для цитування :

O. I. Gonchar, O. I. Synergic approach in marketing potential management of the enterprise / O. I. Gonchar, I. I. Polishchuk // Науковий вісник Полісся. - 2017. - № 3 (11). Ч. 2. - С. 29-33.

Gonchar O. I., Polishchuk I. I. Synergic approach in marketing potential 